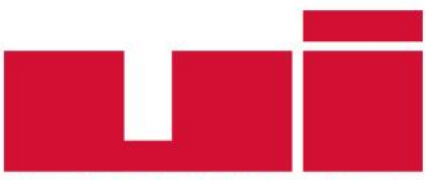

ULLUSLARARASIILIȘKiLER

Akademik Dergi

Yayın ilkeleri, izinler ve abonelik hakkında ayrıntılı bilgi:

E-mail: bilgi@uidergisi.com.tr

Web: www.uidergisi.com.tr

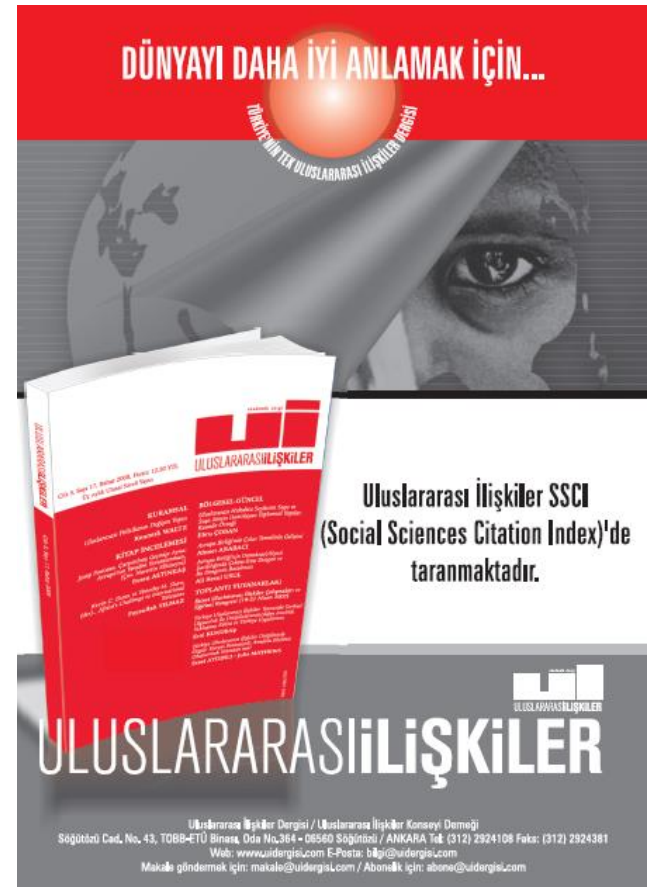

\section{Uluslararası İlişkilerde “Küçük Devletler”: Gelişsimi, Tanımı, Dış Politika ve İttifak Davranışları}

\section{Özlem TÜR* ve Nuri SALIK**}

* Prof. Dr., Uluslararası İlişkiler Bölümü, Orta Doğu Teknik Üniversitesi

** Doktora Adayı, Uluslararası İlişkiler Bölümü, Orta Doğu Teknik Üniversitesi

Bu makaleye atıf için: Tür, Özlem ve Salık, Nuri, "Uluslararası İlişkilerde "Küçük Devletler": Gelişimi, Tanımı, Dış Politika ve İttifak Davranışları“, Uluslararası İlişkiler, Cilt 14, Sayı 53, 2017, s. 3-22.

Bu makalenin tüm hakları Uluslararası İlişkiler Konseyi Derneği’ne aittir. Önceden yazılı izin alınmadan hiç bir iletişim, kopyalama ya da yayın sistemi kullanılarak yeniden yayımlanamaz, çoğaltılamaz, dağıtılamaz, satılamaz veya herhangi bir şekilde kamunun ücretli/ücretsiz kullanımına sunulamaz. Akademik ve haber amaçlı kısa alıntılar bu kuralın dışındadır.

Aksi belirtilmediği sürece Uluslararası Illişkiler'de yayınlanan yazılarda belirtilen fikirler yalnızca yazarına/yazarlarına aittir. UİK Derneğini, editörleri ve diğer yazarları bağlamaz. 


\title{
Uluslararası İlişkilerde “Küçük Devletler”: Gelişimi, Tanımı, Dış Politika ve İttifak Davranışları
}

\author{
Özlem TÜR \\ Prof. Dr., Uluslararası İlişkiler Bölümü, İİBF, Orta Doğu Teknik Üniversitesi, Ankara. \\ E-posta:tur@metu.edu.tr \\ Nuri SALIK \\ Doktora Adayı, Uluslararası İlişkiler Bölümü, İİBF, Orta Doğu Teknik Üniversitesi, Ankara. \\ E-posta:nurisalik@gmail.com
}

\begin{abstract}
ÖZET
Bu makalenin amacı, Uluslararası İlişkiler disiplini içinde ele alınan küçük devlet kavramını incelemek, tanımlamadaki çelişkileri ve farklılıkları ortaya koymak ve küçük devletlerin dış politika ve ittifak davranışları üzerine oluşan literatürü tartışmaktır.Makalede, küçük devletlerin tanımıhususundaüzerinde anlaşılan tekbiryaklaşımın olmadığı, bu devletlerin dış politika davranışları ve ittifak arayışlarını ele alan çalışmalarda da yaklaşım çeşitliliği olduğu vurgulanacaktır. Makale, bu çeşitliliğin küçük devletler kategorisinin ne derece anlamlı olduğunu sorgulamamıza neden olduğunu irdelerken, diğer taraftan bu durumun disiplindeki genel gelişmeleri ve kuramsal tartısmaları yansıttığını göstermeye çalı̧acaktır. Gerek tanımdaki farklılıkların gerekse dış politika ve ittifak davranışlarındaki çeşitliliğin, küçük devletler kategorisinin Uluslararası İlişkiler disiplininin çatışan kuramlarından yararlanan araştırmacılar tarafindan farklı perspektiflerden ele alınmasına yol açtığının altı çizilecektir.
\end{abstract}

Anahtar Kelimeler: Küçük Devletler, Dış Politika, İttifak, Uluslararası İlişkiler.

\section{"Small States" in International Relations: Development, Definition, Foreign Policy and Alliance Behavior}

\begin{abstract}
The aim of this article is to analyze the concept of small states in the discipline of International Relations to show differences and contradictions in the definition and to discuss the literature on foreign policy and alliance behavior of small states. The article emphasizes that there has not been a single approach to the definition of small states and there is diversity in the studies dealing with foreign policy and alliance behavior of these states. While the article enables us to question to what extent this diversity makes the category of small states meaningful, on the other hand, it tries to show that this situation reflects the developments and theoretical discussions in the discipline. Differences in defining small states and diversity of foreign policy and alliance behavior lead scholars, who benefit from contending theories of International Relations, to deal with the category of small states from different perspectives.
\end{abstract}

Keywords: Small States, Foreign Policy, Alliance, International Relations. 


\section{Giriş}

Küçük devletler ve dış politikaları, Uluslararası İlişkiler disiplini içinde bir araştırma alanı olarak Soğuk Savaş döneminde ortaya çıkmıştır. İkinci Dünya Savaşı’nın ardından başlayan sömürgelerin bağımsızlıklarını kazanma (decolonisation) süreciyle birlikte dünya genelinde birçok küçük devlet bağımsızlı̆̆ını kazanmış, bu yeni devletler uluslararası sistemin işleyişi için önemli bileşenler olarak görülmeye başlanmıştır. Bu nedenle, genel anlamda ABD ve SSCB gibi büyük devlet politikalarıyla ilgilenen Uluslararası İlişkiler disiplinine küçük devlet çalışmalarının dâhil edilmesinin uluslararası politikanın anlaşılmasına yeni boyutlar kazandıracağı öne sürülmüştür. Bu bağlamda, uluslararası sistem büyük devletlerden ziyade küçük devletlerden oluştuğu için bu devletlerin dış politikalarının çalışılmasına önem verilmeye başlanmıştır.

Bu makalenin amacı, Uluslararası İlişkiler disiplini içinde ele alınan küçük devlet kavramını incelemek, tanımlamadaki çelişkileri ve farklılıkları ortaya koymak ve küçük devletlerin dış politika ve ittifak davranışları üzerine oluşan literatürü tartışmaktır. Makalede küçük devletlerin tanımı konusunda üzerinde anlaşılan tek bir yaklaşım olmadığı ortaya konulacak, bu devletlerin dış politika davranışları ve ittifak arayışlarına odaklanan çalışmalarda da pek çok farklı yaklaşımın varlığına dikkat çekilecektir. Makale, yaklaşımlardaki çeşitliliğin bir taraftan küçük devletler kategorisinin ne derece anlamlı olduğunu sorgulamamıza neden olduğunu irdelerken, diğer taraftan bu çeşitliliğin disiplindeki genel gelişmeler ve kuramsal tartışmalar ile doğrudan ilgili olduğunu göstermeye çalışacaktır.

Gerek küçük devletleri tanımlarken ortaya çıkan muğlaklık, gerekse bu devletlerin dış politika ve ittifak davranışlarındaki çeşitlilik ve çelişkiler araştırmacıların dünyanın çeşitli bölgelerindeki küçük devletleri incelerken farklı Uluslararası İliş̧kiler kuramlarından yararlanmasına neden olmuştur. Bu bağlamda, küçük devletlerin dış politikalarının farklı kuramsal perspektiflerden analiz edilmesinin ve bu konudaki literatürün tartışılmasının disipline önemli katkılar sağladığı görülmektedir. $\mathrm{Bu}$ tartışmanın Türkçe Uluslararası İlişkiler literatürüne de önemli katkıda bulunacağı düşünülmektedir. Makalede öncelikle küçük devletlerin ve küçük devlet çalışmalarının tarihsel gelişimi incelenecektir. Daha sonra küçük devletlerin tanımı üzerine var olan tartışmalar ve değişik kriterleri uygulayan çalışmalar ele alınacaktır. Makalede son olarak, küçük devletlerin dış politika ve ittifak davranışlarını inceleyen çalışmalar tartışılacaktır.

\section{Küçük Devletlerin ve Küçük Devlet Çalışmalarının Tarihsel Gelişimi}

Uluslararası politikada küçük devletler (small states) veya küçük güçler (small powers) kategorisi, büyük güçler (great powers) olarak adlandırılan devletlerin 1815 yılında Viyana Kongresi’nde yasal bir kategori olarak benimsenmesiyle ortaya çıkmıştır. Viyana Kongresi’nden Birinci Dünya Savaşı́na kadar geçen yüz yıllık süre içerisinde uluslararası arenada küçük devletler/güçler kategorisi, büyük devletler kampı dışında kalan devletler için kullanılmıştır. ${ }^{1}$ Küçük devlet çalışmalarının tarihi de buna paralel olarak Avrupa siyasi düşüncesinde 18. ve 19. yüzyıllara kadar gitmektedir. 19. yüzyılın ikinci yarısından itibaren küçük devletlerin özellikle Alman entelektüelleri tarafından negatif bir bağlamda çalışıldığı görülmektedir. Bunun nedeni, küçük Alman devletlerinin milliyetçilik ve ulus-devlet çağında Alman ulusal birliğinin önün-

1 1815-1914 yılları arasında Fransa, Rusya, Britanya, Avusturya-Macaristan, Almanya ve İtalya büyük güçler olarak kabul edilmiştir. Iver B. Neumann ve Sieglinde Gstöhl, "Introduction: Lilliputians in Gulliver's World”, Christine Ingebritsen et.al. (der.), Small States in International Relations, Seattle, University of Washington Press, 2006, s.5-6. 
de engel olarak kabul edilmesidir. ${ }^{2}$ Birinci Dünya Savaşı’nın ardından imparatorlukların yıkılması, Soğuk Savaş döneminde yaşanan sömürgelerin bağımsızlıklarını kazanmaları süreci ve son olarak Sovyetler Birliği ile Yugoslavya’nın dağılması, 20. yüzyıl boyunca küçük devletlerin dünya genelinde sayısının artmasına yol açan üç önemli dönüm noktasıdır. ${ }^{3}$ Küçük devletlerin dünya siyasetinin yeni aktörleri olarak ortaya çıkması ve uluslararası örgütlerde bu devletlerin önem kazanmaya başlaması, akademik çevrelerde küçük devletlere ve dış politikalarına yönelik yeni bir ilgi uyandırmıştır.

Uluslararası İlişkiler disiplininde küçük devlet çalışmaları, Annette Baker Fox'un 1959 yılında yayımlanan The Power of Small States: Diplomacy in World War II adlı kitabından sonra öne çlkmaya başlamıştır. Bu çığır açıcı eserinde Fox, İkinci Dünya Savaşı sırasında küçük devlet olarak adlandırdığı beş devletin dış politikasını ve bu devletlerin büyük güçler olarak adlandırılan ülkelerin baskılarına rağmen nasıl savaş dışında kalmaya çalıştıklarını incelemektedir. Fox, genel olarak uluslararası politikanın güçsüz aktörleri olarak kabul edilen küçük devletlerin tarafsız kalmalarının (neutrality) faydaları hususunda büyük devletleri ikna ederek savaş dışı kalmayı başarabildiklerini öne sürmektedir. Fox, çalışmasında incelediği küçük devletlerin hem jeostratejik konumlarının hem de diplomatik yeteneklerinin önemini vurgulayarak iç ve dış faktörleri birlikte ele almıştır. ${ }^{4}$

Küçük devletler kategorisinin, Uluslararası İlişkiler disiplini içinde yer almaya başladıktan sonra, disiplinin yaşadığı kuramsal dönüşümlerden doğrudan etkilendiği görülmektedir. $\mathrm{Bu}$ bağlamda, küçük devletler literatürünün ilk evresi realist/neorealist uluslararası ilişkiler kuramından, ikinci evresi neorealizm-neoliberal kurumsalcılık tartışmasından ve üçüncü evresi de en çok sosyal inşacılıktan etkilenmiştir. ${ }^{5}$ Fox'un çalışmasının hemen akabinde küçük devlet çalışmaları, Soğuk Savaş'ın ve realist/neorealist Uluslararası İlişkiler kuramının etkisiyle güvenlik ve ittifak konuları üzerine yoğunlaşmıştır. ${ }^{6}$

Bağımsız bir alan olarak küçük devlet çalışmaları, 1970’lerin ortalarından itibaren yaşanan sömürgelerin bağımsızlıklarını kazanma süreciyle birlikte altın dönemini yaşamıştır. Bu dönemde küçük devlet teorisinin hem ekonomi hem de siyasal bilimler alanlarında ciddi gelişme gösterdiği gözlemlenmektedir. Ekonomistler küçük devletlerin ortak ekonomik özellikleri üzerine yoğunlaşırken, neorealistler küçük devletlerin boyutunu ya da göreceli güç kapasitesini önemli bir veri kabul ederek bu devletlerin ortak dış politika davranışları sergileyeceklerini öne sürmüştür.7 1980'ler boyunca ve

2 Niels Amstrup, “The Perennial Problem of Small States: A Survey of Research Efforts”, Cooperation and Conflict, Cilt 11, No.4, 1976, s.163-164.

3 Asbed Kotchikian, The Dialectics of Small States, Foreign Policy Making in Armenia and Georgia, Saarbrücken, VDM Verlag Dr. Müller, 2008, s.13-14; Neumann ve Gstöhl, “Introduction: Lilliputians in Gulliver's World”, s.5.

4 Annette Baker Fox, The Power of Small States: Diplomacy in World War II, Chicago, The University of Chicago Press, 1959.

5 Neumann ve Gstöhl, “Introduction: Lilliputians in Gulliver’s World”, s.15.

6 Bu dönemde küçük devletler üzerine yapılan bazı çalışmalar şunlardır: Robert L. Rothstein, Alliances and Small Powers, New York, Columbia University Press, 1968; Robert L. Rothstein, "Alignment, Nonalignment, and Small Powers: 19451965”, International Organization, Cilt 20, No.3, 1966, s.397-418; David Vital, The Inequality of States: A Study of Small Power in International Relations, Oxford, Clarendon Press, 1967; George Liska, Alliances and the Third World, Baltimore, Johns Hopkins University Press, 1968; Robert O. Keohane, "Lilliputians' Dilemmas: Small States in International Politics”, International Organization, Cilt 23, No.2, 1969, s.291-310.

7 Neumann ve Gstöhl, "Introduction: Lilliputians in Gulliver's World", s.11. Ayrıca bkz. David Vital, The Survival of Small States: Studies in Small Power/Great Power Conflict, Oxford, Oxford University Press, 1971; Marshall R. Singer, Weak States in a World of Powers: The Dynamics of International Relationships, New York, The Free Press, 1972; Trygve Mathisen, The Functions of Small States in the Strategies of the Great Powers, Oslo, Universitetsforlaget, 1971; Maurice A. East, "Size and Foreign Policy Behaviour: A Test of Two Models", World Politics, Cilt 25, No.4, 1973, s.556-576; August Schou ve Arne Olav Brundtland (der.), Small States in International Relations, Stockholm, Almqvist\&Wiksell, 1971; Robert O. Keohane, “The Big Influence of Small Allies”, Foreign Policy, Cilt 1, No.2, 1971, s.161-182. 
1990’ların başında küçük devlet çalışmalarının bir duraklama dönemine girdiği görülmektedir. Bu dönemde, devletlerin boyutunun önemli bir kategori olarak görülmemesi nedeniyle, akademisyenler arasında ilgi genel uluslararası ilişkiler kuramlarına kaymıştır. Küçük devlet çalışmaları ise daha çok neoliberalizmin neorealizme olan eleştirileri etrafında belirginleşen yeni yaklaşımlar etrafında yapılmıştır. Bu bağlamda, küçük devletlerin küresel ekonomik sistem ile uluslararası kurumlar ve rejimler çerçevesinde analiz edildiği görülmektedir. ${ }^{8}$

Berlin Duvarı́nın yıkılmasıyla birlikte Orta ve Doğu Avrupa ile Balkan ve Baltık bölgelerinde yeni küçük devletlerin bağımsızlıklarını kazanmalarının yanı sıra, küreselleşme ve bölgesel entegrasyon gibi meselelerin gündeme gelmesi Soğuk Savaş sonrası dönemde küçük devlet çalışmalarının yeniden önem kazanmasına yol açan başlıca gelişmelerdir. Ayrıca, yeni kurulan küçük devletlerin Avrupa Birliği ve NATO gibi uluslararası örgütlere üyelik süreçleri, iç ihtilafları ve dış güvenlikleri gibi konular gündemi meşgul etmeye başlamıştır. Bütün bu faktörlerle beraber, uluslararası ilişkilerde güç ve uluslararası kurumların yerine normları ve kimlikleri ön plana çıkaran sosyal inşacılık kuramının yükselmeye başlaması küçük devlet çalışmalarının yeni bir boyut kazanmasına neden olmuştur. Sonuç olarak, küçük devletlerin dış politikaları hem güvenlik hem de kimlik faktörü etrafında çalışılmaya başlanmıştır. ${ }^{9}$

Yukarıda anlatılan küçük devlet çalışmalarının gelişimi şu şekilde özetlenebilir:

\begin{tabular}{|l|l|l|l|}
\hline Tarihi Olaylar & $\begin{array}{l}\text { 1950-1970: en parlak } \\
\text { dönem } \\
\text { Soğuk Savaş anlaşmazlı̆̆ı; } \\
\text { dekolonizasyon ve küçük } \\
\text { devlet sayısındaki artış }\end{array}$ & $\begin{array}{l}\text { 1980’ler: duraklama } \\
\text { ABD hegemonyasının } \\
\text { zayıflaması, küresel } \\
\text { bağımlılığın artması. }\end{array}$ & $\begin{array}{l}\text { 1990'lar: yeniden } \\
\text { canlanma } \\
\text { Soğuk Savaş'ın sonu, } \\
\text { küreselleşme ve bölgesel } \\
\text { entegrasyon, dağılmalar } \\
\text { ve küçük devlet } \\
\text { sayısındaki artış }\end{array}$ \\
\hline $\begin{array}{l}\text { Hâkim } \\
\text { Illişkiler Teorisi }\end{array}$ & Realizm/Neorealizm & $\begin{array}{l}\text { Neorealizm ve Neoliberal } \\
\text { Kurumsalcılık }\end{array}$ & $\begin{array}{l}\text { Rasyonalizm ve Sosyal } \\
\text { İnşacılık }\end{array}$ \\
\hline $\begin{array}{l}\text { Küçük Devlet } \\
\text { Konuları }\end{array}$ & $\begin{array}{l}\text { Küçük devletlerin tanımı, } \\
\text { büyüklük ve diş politika, } \\
\text { güvenlik meseleleri, } \\
\text { uluslararası örgütlerde } \\
\text { küçük devletler }\end{array}$ & $\begin{array}{l}\text { Küçük devletler ve } \\
\text { ekonomik bağımlılık ve } \\
\text { kalkınma meseleleri }\end{array}$ & $\begin{array}{l}\text { küreselleşme süreçlerinde } \\
\text { küçük devletler, etnik- } \\
\text { siyasi çatışmalar }\end{array}$ \\
\hline
\end{tabular}

Kaynak: Neumann ve Gstöhl “Introduction: Lilliputians in Gulliver’s World”, s.16.

8 Neumann ve Gstöhl, “Introduction: Lilliputians in Gulliver’s World”, s.12-13. Ayrıca bkz. Otmar Höll (der.), Small States in Europe and Dependence, Viyana, Wilhelm Brumüller, 1983; Peter J. Katzenstein, Small States in World Markets: Industrial Policy in Europe, Ithaca, Cornell University Press, 1985; Stephen D. Krasner, "Transforming International Regimes: What the Third World Wants and Why”, International Studies Quarterly, Cilt 25, No.1, 1981, s.119-148.

9 Neumann ve Gstöhl, “Introduction: Lilliputians in Gulliver's World”, s.13-14. Ayrıca bkz. Werner Bauwens et.al. (der.), Small States and the Security Challenge in the New Europe, Londra, Brassey's, 1996; Laurent Goetschel (der.), Small States Inside and Outside the European Union: Interests and Policies, Dordrecht, Kluwer Academic Publishers, 1998; Efraim Inbar ve Gabriel Sheffer, The National Security of Small States in Changing World, Londra, Frank Cass, 1997; Christopher S. Browning, "Small, Smart and Salient? Rethinking Identity in the Small States Literature," Cambridge Review of International Affairs, Cilt 19, No.4, 2006, s.669-684. 


\section{Küçük Devletleri Tanımlama Modelleri: Niceliksel, Niteliksel ve Algısal Yaklaşımlar}

Küçük devletlerin bağımsız bir çalışma alanı olarak ortaya çıkışından günümüze kadar geçen süreç içerisinde yaşadığı en büyük problemin “tanım” belirsizliği olduğu ifade edilebilir. Her ne kadar küçük devlet kavramı üzerine yapılan çalışmaların büyük çoğunluğu tanım üzerine yoğunlaşsa da, konu ile ilgilenen yazarların üzerinde görüş birliğine vardığı bir küçük devlet tanımı henüz bulunmamaktadır. Farklı perspektiflerden yapılan küçük devlet çalışmaları, çok sayıda küçük devlet tanımına yol açarak sabit ve birleşik bir tanımın ortaya çıkmasının önüne geçmiştir.

Iver Neumann ve Sieglinde Gstöhl’e göre, küçüklük göreceli bir kavramdır ve küçük devletler arta kalan (residual) bir kategoridir. Küçük devletler, onların ne olmadığına bakılarak tanımlanmakta, yani uluslararası politikada ne orta ne de büyük güç olan bir kategori olarak ifade edilmektedir. Uluslararası sistem göz önüne alınarak küçük devletler, karşılaştırmalı bir perspektiften, mikro devletlerden büyük, orta ve büyük güçlerden daha küçük devletler olarak tanımlanmaktadır. ${ }^{10}$ Fakat bu bakış açısının yol açtı̆ğ sorunun başında küçük devletleri küçük olmayan devletlerden ayırt edecek çizgilerin açık ve net bir biçimde belirlenememiş olması bulunmaktadır. ${ }^{11}$

Küçük devlet çalışmaları incelendiğinde şu ana kadar genel olarak üç temel tanımlama modelinin geliştirildiği ileri sürülebilir. Bu tanımlama modelleri niceliksel (quantitative), niteliksel (qualitative) ve algısal (perceptional) yaklaşımlara dayanmaktadır. Bu modellerden ilki niceliksel yaklaşımdır ve devletlerin küçüklüğünü nüfus, toprak parçası ve Gayri Safi Yurtiçi Hâsıla (GSYİH)/ ekonomik gelişmişlik düzeyi gibi objektif materyal kriterlere dayanarak açıklamaya çalışmaktadır. Küçük devlet kategorisini niceliksel model ile tanımlayanlar arasında en sistemli yöntemlerden birini Tom Crowards geliştirmiştir. Nüfus, toprak parçası ve GSYIH gibi parametreleri birlikte ele alan Crowards, kümeleme analizi yöntemini kullanarak devletleri mikro, küçük, orta-ölçekli, büyük ve çok büyük olarak sınıflandırmaktadır. ${ }^{12}$

Niceliksel yaklaşımların geneline bakıldığında, nüfusun bir devletin küçüklügünü belirlemek için en çok kabul edilen kriter olduğu gözlemlenmektedir. ${ }^{13}$ Ülkenin insan kaynakları ve yerel pazarının yaklaşık büyüklüğü hakkında fikir vermesi açısından da nüfus kriteri ön plana çıkmaktadır. ${ }^{14}$ Örneğin, küçük devletler üzerine yapılan önemli çalışmalardan biri olan David Vital'in The Inequality of States: A Study of Small Power in International Relations adlı eserinde küçük devlet kriterleri şu şekilde belirtilmektedir: a) ekonomik olarak gelişmiş ülkeler için 10-15 milyon nüfusa sahip olmak; b) azgelişmiş ülkeler için 20-30 milyon nüfusa sahip olmak. ${ }^{15}$ Bir diğer yazar Jean Luc-Vellut, devletleri büyük güçler, orta ölçekli (medium) güçler, küçük güçler ve daha küçük güçler olarak dörde ayırarak küçük devlet kriterlerini 10-50 milyon arası nüfus ve 2-10 milyar dolar arası GSYİH olarak

\footnotetext{
10 Ibid., s.5-6, 8-9.

11 Jeanne A. K. Hey, "Introducing Small State Foreign Policy”, Jeanne A. K. Hey (der.), Small States in World Politics: Explaining Foreign Policy Behavior, Boulder, Lynne Rienner Publishers, 2003, s.3; Kotchikian, The Dialectics of Small States, s.17.

12 Tom Crowards, "Defining the Category of Small States", Journal of International Development, Cilt 14, No.2, 2002, s.160173. Crowards çalışmasında 188 ülke içerisinde 79 devleti (mikro devletler dâhil) küçük devlet olarak tespit etmektedir.

13 Küçük devletleri nüfuslarına bakarak tanımlayan çalışmaların bir listesi için bkz. Crowards, "Defining the Category of Small States", s.177-179.

14 Björn G. Ólaffson, Small States in the Global System: Analysis and Illustrations from the Case of Iceland, Aldershot, Ashgate, 1998, s.8; Crowards, "Defining the Category of Small States", s.143.

15 Vital, The Inequality of States, s.8.
} 
belirlemiştir. ${ }^{16}$ Roland Barston ise küçük devlet kategorisinin nüfus üst limitini 10-15 milyon olarak belirtmekte, küçük devletlerin çoğunlukla ekonomik olarak azgelişmiş ülkeler olduğunu ve Gayri Safi Milli Hasılalarının (GSMH) genellikle yıllık 10 milyar Dolar'dan az olduğunu ifade etmektedir. ${ }^{17}$

Neumann ve Gstöhl, Avrupa bağlamında küçük devletleri tanımlamak için Hollanda nüfusunun (16 milyon) kıstas olarak kabul edildiğini belirtmektedir. Buna göre Rusya, Almanya, Türkiye, Fransa, İtalya, Britanya, Ukrayna, İspanya, Polonya ve Romanya dışında kalan ülkeler Avrupa içerisinde küçük devlet olarak kabul edilmektedir. ${ }^{18}$ Robert Steinmetz ve Anders Wivel ise, küçük devletler ile büyük devletler arasında bulunan kesin ve evrensel sınırı nüfus için 15 milyon, GSYİH için 500 milyar Euro olarak çizerek bu kriterler altında kalan ülkelerin kolaylıkla küçük devlet olarak tanımlanabileceğini belirtmektedir. ${ }^{19}$ Fakat Steinmetz ve Wivel'in öne sürdügü bu rakamlar da tıpkı diğerlerinin belirttiği gibi keyfi olmaktan öteye gidememiş ve genel bir küçük devlet tanımı için nihai kriterler olamamıştır.

Küçük devlet çalışmalarının gelişimi boyunca, nüfus kriterinin 1950’ler ve 1960’larda yaklaşık 10-15 milyondan 1990’lara gelindiğinde 1-1,5 milyona doğru düştüğü görülmektedir. Bu durumun en önemli nedeni, çok küçük devletlerin ve ada devletlerinin ortaya çıkmasıdır. ${ }^{20}$ Örneğin, İngiliz Milletler Topluluğu (Commonwealth) Sekreterliği küçük devletleri "1,5 milyon insan veya daha az nüfusa sahip egemen devletler” olarak tanımlamaktadır. Dünya Bankası ve Commonwealth Sekreterliğine göre, 44 ülke küçük devlet olarak kategorize edilmekte; Commonwealth' in 54 üyesinden 32 tanesi küçük devlet olarak kabul edilmektedir. ${ }^{21}$ Anthony Payne, küçük devletler için nüfus kriterini yaklaşık 1 milyon veya daha az olarak belirtmektedir. ${ }^{22}$ Dana Ott, küçük devletlerin nüfus kriterinin 100 bin ile 1,5 milyon arasında olması gerektiğini ifade etmektedir. ${ }^{23}$ Benzer şekilde Björn G. Ólaffson, küçük devletlerin nüfusuyla ilgili yaklaşık 1 milyonu üst limit olarak kabul etmektedir. ${ }^{24}$

Nüfus, ulusal gelir ve yüzölçümü gibi parametrelerin herkes tarafindan kabul edilen kesin sınırlarının bir türlü belirlenememesi, niceliksel yaklaşım üzerine inşa edilen küçük devlet tanımlarının keyfi bir niteliğe bürünmesine neden olmuştur. Bu sebeple, bazı yazarlar küçük devletlerin uluslararası politikada güç kapasitelerinive güçilişkilerini temel alan niteliksel yaklaşımı geliştirmişlerdir. Steinmetz ve Wivel'e göre, güç boyutunun küçük devlet çalışmaları için temel alınması, küçük devletlerin ve büyük güçlerin genel anlamda uluslararası ilişkiler ve dış politika çalışmalarında karşılaştırmalı olarak ele alınmaları açısından yeni açılımlar sağlamaktadır. ${ }^{25}$ Küçük devletleri güç parametresi üzerinden tanımlayanların başında Laurent Goetschel gelmektedir. Goetschel, güç kavramını pozitif ve negatif anlamlarda kullanmaktadır. Pozitif anlamda güç, bir aktörün kendi isteği doğrultusunda diğerlerinin davranışlarını değiştirme kapasitesidir. Negatif anlamda ise, bir aktörün kendi davranışına diğerlerinin etkisini engelleme kapasitesidir. Birinci yaklaşım etkiye (influence), ikincisi otonomiye

16 Jean-Luc Vellut, "Smaller States and the Problem of War and Peace: Some Consequences of the Emergence of Smaller States in Africa", Journal of Peace Research, Cilt 4, No.3, 1967, s.254.

17 Roland P. Barston, “The External Relations of Small States”, August Schou ve Arne Olav Brundtland (der.), Small States in International Relations, Stockholm, Almqvist\&Wiksell, 1971, s.41.

18 Neumann ve Gstöhl, "Introduction: Lilliputians in Gulliver's World”, s.6.

19 Robert Steinmetz ve Anders Wivel, “Introduction”, Robert Steinmetz ve Anders Wivel (der.), Small States in Europe: Challenges and Opportunities, Aldershot, Ashgate, 2010, s.5.

20 Crowards, "Defining the Category of Small States", s.145.

21 "Small States", http://secretariat.thecommonwealth.org/Internal/180407/ (Erişim Tarihi: 10 Ağustos 2015).

22 Anthony Payne, "Small States in the Global Politics of Development", The Round Table: The Commonwealth Journal of International Affairs, Cilt 93, No.3, 2004, s.625-626.

23 Dana Ott, Small is Democratic: An Examination of State Size and Democratic Development, New York, Garland Publishing, 2000, s.18.

24 Ólaffson, Small States in the Global System, s.11.

25 Steinmetz ve Wivel, "Introduction", s.5. 
(autonomy) işaret etmektedir. Goetschel, güç ilişkileri açısından, küçük devletlerin büyük devletlere göre daha güçsüz olduğunu ve uluslararası ortamda hem etki hem de otonomi eksikliği olduğunu vurgulamaktadır. ${ }^{26}$ Goetschel'e göre:

Devletlerin teritoryal uzamları veya nüfus büyüklüğüne göre sınıflandırılması önceden büyük önemdeydi. Bugün stratejik derinlik ve askeri insan gücü olarak tanımlanan temel faktörler devletlerin hayatta kalmasını etkilemektedir. Küçük devletler sadece diğerlerinden daha küçük değildir; bu göreceli niteliğin kesin sonuçları olmalıdır. Küçüklüğün önemi güç kavramına ve uluslararası sistemin doğasına dayanmaktadır. ${ }^{27}$

Güç parametresine ve ilişkisel boyuta bakarak küçük devletleri tanımlayan Olav Knudsen'e göre, "küçük devlet, başka bir devletle belirgin bir aşağı güç ilişkisi içinde bulunan herhangi bir devlet olabilir."28 Aynı şekilde Erling Bjøl de ilişkisel açıdan bir tanımlamanın önemine dikkat çekmektedir:

Tek başına küçük devlet kavramının hiçbir anlamı yoktur. Bir devlet sadece büyük bir devlete kıyasla küçüktür. Belçika, Fransa’ya kıyasla küçük olabilir, fakat Lüksemburg Belçika’ya kıyasla küçük, Fransa da ABD'ye kıyasla küçüktür. Bu nedenle, küçük devletin analitik kullanımı 'bir devletin büyük bir devletle ilişkilerine' atıfta bulunularak ele alınmalıdır. ${ }^{29}$

Dilaver Arıkan Açar, ilişkisel perspektiften ve güç göreceliliği açısından küçük devlet tanımlamasına Susan Strange'in ilişkisel güç (relational power) ve yapısal güç (structural power) kavramlarını kullanarak katkıda bulunmaktadır. Açar’a göre, küçük devletlerin sadece bir devletin diğer devletlerle olan ilişkisinde sahip olduğu güç anlamına gelen ilişkisel gücü olabilir. Diğer taraftan, büyük güçler bir devletin küresel düzeyde sonuçları etkileme kapasitesi anlamına gelen yapısal güce sahiptir. Bu nedenle, niteliksel yaklaşım ya da küçük devletlerin sınırlı güç kapasitesi onların uluslararası arenadaki pozisyonlarını belirlemektedir. ${ }^{30}$

Her ne kadar bu yaklaşımda küçük devletler güç dengesinin zayıf tarafı olarak ortaya çıksa da, bu noktada ilişkisellik ve görecelilik göz önünde bulundurulmalıdır. Örneğin, bir devlet diğer bir devlet ile olan ilişkisinde güçlü tarafken, bir başka devlet ile olan ilişkisinde zayıf taraf olabilir. Steinmetz ve Wivel'den aktaracak olursak,

... bir devlet bir ilişkide zayıf, aynı anda bir diğerinde güçlü olabilir. Örneğin Romanya, Moldova ile ilişkilerinde büyük güç fakat Rusya ile ilişkilerinde küçük devlettir. Bu nedenle, küçük devlet olmanın spesifik bir zaman-mekân bağlamına bağlı olduğunu ve bu bağlamın, diğer devletlere kıyasla kesin nüfus veya GSYİH büyüklügü gibi göstergelere bakılarak tanımlanan devletlerin genel karakteristiklerinden ziyade, tehditlerin ve firsatların doğası için ve küçük devletlerin bu tehditlere ve firsatlara verdiği cevaplar için belirleyici olduğunu iddia edebiliriz. ... küçüklük, devlet ve onun dış ortam ile ilişkisi üzerinden tanımlanmalıdır. ${ }^{31}$

26 Laurent Goetschel, “The Foreign and Security Policy Interests of Small States in Today's Europe”, Laurent Goetschel (der.), Small States Inside and Outside the European Union: Interests and Policies, Dordrecht, Kluwer Academic Publishers, 1998, s.14-15.

27 Laurent Goetschel, Small States and the Common Foreign and Security Policy (CFSP) of the EU: A Comparative Analysis, Bern, Institut für Politikwissenschaft, 2000, NFP 42 Working Papers, Paper 14, s.3.

28 Olav F. Knudsen, "Small States, Latent and Extant: Towards a General Perspective”, Journal of International Relations and Development, Cilt 5, No.2, 2002, s.184-185.

29 Erling Bjøl, “The Small State in International Politics”, August Schou ve Arne Olav Brundtland (der.), Small States in International Relations, Stockholm, Almqvist\&Wiksell, 1971, s.29-30.

30 Dilaver Arıkan Açar, Small State Playing the Asymmetric Game: Continuity and Change in Albanian Foreign Policy, Basılmamış Doktora Tezi, Ankara, Orta Doğu Teknik Üniversitesi, Sosyal Bilimler Enstitüsü, 2008, s.20-21.

31 Steinmetz ve Wivel, "Introduction”, s.6-7. 
Küçük devlet tanımının güç ve uluslararası düzeyde güç ilişkileri açısından yapılması, küçük devletleri zayıf devletler (weak states) ile özdeş gören bir anlayışın ortaya çıkmasına ve yeni tartışmaların yaşanmasına neden olmuştur. Örneğin, küçük devlet kavramının güç eksikliği etrafında tanımlanması gerektiğini belirten Michael Handel, zayıf devlet kavramını geniş anlamıyla küçük ya da büyük toprak parçasına sahip bütün devletler için kullanmaktadır. ${ }^{32}$

Miriam Fendius Elman da zayıf, küçük ve güvensiz devletleri aynı anlamda kullanmakta ve küçük devletleri güç parametresi üzerinden tanımlamaktadır. ${ }^{33}$ Neumann ve Gstöhl, bu yaklaşımı reddederek küçük devletleri zayıf devletlerle özdeş görmenin bir gereklilik olmadığını, küçüklügün (smallness) nicelik veya fiziksel büyüklükle ilgili olduğunu, zayıflığın (weakness) ise nitelik ve güç kapasitesiyle ilgili olduğunu iddia etmektedir. ${ }^{34}$ Paralel bir şekilde, Kotchikian da küçüklügün fiziksel büyüklük, zayıflı̆ın ise kapasite ile ilgili olduğunu belirterek iki kavramı birbirinden ayırmaktadır. ${ }^{35}$ İsrail örneği bu bağlamda önemlidir. Toprak açısından küçük bir devlet olan İsrail bölgesel ve küresel düzeyde çok daha büyük etkiye sahiptir. Küçük bir toprak parçasına sahip olan İsrail'in Afrika'da ve Asya'da kendisinden toprak olarak daha büyük devletlere oranla daha güçlü olduğu bir gerçektir. ${ }^{36}$

Küçük devlet kategorisinin tanımlanmasıyla ilgili üçüncü model ise algısal yaklaşımı esas almaktadır. Robert Rothstein, küçük devleti algısal yaklaşımla tanımlayan ilk yazarlardan biridir. Rothstein, algısal perspektiften küçük devleti şu şekilde tanımlamaktadır: "güvenliğini öncelikle kendi imkânlarına dayanarak sağlayamayacağını ve güvenlik için temel olarak başka devletlerin, kurumların ya da gelişmelerin yardımına dayanmak zorunda olduğunu kabul eden devlettir." ${ }^{37}$ Jeanne Hey, küçük devleti algısal yaklaşıma göre tanımlayan bir diğer isimdir. Hey, küçük devleti tanımlarken şunları söylemektedir: "küçük devlet kavramı algı düşüncesine dayanmaktadır. Yani, bir devletin halkı ve kurumları genel anlamda kendisini küçük olarak algılıyorsa veya diğer devletlerin halkları ve kurumları söz konusu devleti küçük devlet olarak algılıyorsa, devlet bu şekilde (küçük) kabul edilmelidir." ${ }^{38}$

Robert O. Keohane de benzer bir biçimde küçük devlet kategorisini algısal yaklaşımla tanımlamakta ve bunu yaparken sistemik düzeyin önemine dikkat çekmektedir: "küçükgüç, liderlerinin kendi başlarına veya küçük bir grup içerisinde hareket ederek hiçbir zaman sistem üzerinde önemli bir etkide bulunamayacağını kabul ettiği devlettir." ${ }^{39}$ Bu bağlamda Keohane, uluslararası sistem içinde devletleri dört kategoriye ayırmaktadır: sistem-karar verici devletler (ABD ve Sovyetler Birliği), sistem-etkileyici devletler (Britanya, Fransa, Çin, Batı Almanya, Japonya ve Hindistan), sistem-etkin devletler (Kanada, İsveç, Pakistan, Brezilya ve Arjantin) ve sistem-etkisiz devletler (diğer devletler). Keohane'e göre, küçük devletler sistem etkisi olmayan devletlerdir. ${ }^{40}$

32 Michael Handel, Weak States in the International System, Londra, Frank Cass, 1990, s.10-11.

33 Miriam Fendius Elman, “The Foreign Policies of Small States: Challenging Neorealism in Its Own Backyard”, British Journal of Political Science, Cilt 25, No.2, 1995, s.171.

34 Neumann ve Gstöhl, “Introduction: Lilliputians in Gulliver’s World”, s.7-8.

35 Kotchikian, The Dialectics of Small States, s.21.

36 Hey, "Introducing Small State Foreign Policy", s.2-3.

37 Rothstein, Alliances and Small Powers, s.29.

38 Hey, "Introducing Small State Foreign Policy", s.3.

39 Robert O. Keohane, “Lilliputians' Dilemmas: Small States in International Politics”, Christine Ingebritsen et.al. (der.), Small States in International Relations, Seattle, University of Washington Press, 2006, s.59.

40 Ibid., s.59-60. 
Benzer bir yaklaşım Annette Baker Fox tarafindan önerilmektedir:

Bizi asıl olarak ilgilendiren şey bütün uluslararası sistem olduğu için, küçük devletleri, liderlerinin (ve diğer devlet liderlerinin) kendi devletinin siyasi ağırlı̆̆ının küreselden ziyade yerel alanla sınırlı olduğunu, güvenliklerinin büyük çoğunluğu için dış siyasi güçlere dayandığını ve özel devlet çıkarlarının bir veya birden fazla büyük güç nazarında vazgeçilebilir olduğunu kabul ettiği devlet olarak düşünebiliriz. ${ }^{41}$

Şurası açıtır ki bir devlet kendisini büyük devlet ilan ederek büyük devlet olamaz. Büyük devlet olarak kabul edilebilmesi için o devletin maddi ve güç kapasitesinin başka devletler tarafindan da kabul edilmesi gerekmektedir. ${ }^{42} \mathrm{Bu}$ nedenle, bir devletin küçük veya büyük olması durumu, algısal yaklaşımın dışında güçle de desteklenmelidir. Zaten küçük devleti algısal modelle tanımlayan Rothstein, Keohane ve Fox'un da çalışmalarında güç eksikliğini üstü kapalı olarak göz önünde bulundurdukları ifade edilebilir.

Küçük devlet çalışmalarının gelişimi boyunca, yukarıda ele alınan bu üç yaklaşımı birden içeren eklektik tanımlamaların ya da bunların dışında daha geniş kriterleri uygulayan tanımlamaların yapıldığı da görülmektedir. Örneğin, Raimo Värynen küçük devletleri tanımlamak için beş farklı boyuta bakılabileceğine dikkat çekmektedir. Bunlar, algısal ya da somut verilere dayanan iç ve dış boyutlu düşük statü/derece, yüksek düzeyli dış müdahale, belirli bir davranış biçimi, diğer devletlere oranla farklı çıkarlar gözetme ve bulunduğu sistem içinde belirli bir rol oynama olarak belirtilebilir. ${ }^{43}$ Värynen, bu beş yaklaşımdan derece (rank) ve rol (role) faktörlerini küçük devlet tanımı için temel bileşenler olarak benimsediğini belirterek şöyle bir tanımlama yapmaktadır:

Bir küçük güç, hareket ettiği bağlam içerisinde düşük düzeyli algısal ve/veya objektif derecesi olan devlettir. Bunun yanı sıra, küçük devletlerden belirli bir biçimde davranması beklenmektedir, yani onların davranış yönelimleri orta ölçekli ve büyük güçlerden ayrıdır. ... Son olarak, küçük devletlerin çıkarları en azından bir dereceye kadar büyük devletlerin çıkarlarından farklıdır... ${ }^{44}$

Sonuç olarak, Jeanne Hey'in belirttiği gibi küçük devlet kategorisiyle ilgilenen bütün yazarlar temel olarak üç devlet tipine atıfta bulunmaktadırlar: nüfusu 1 milyonun altında olan mikro devletler, gelişmiş dünyadaki küçük devletler ve bu ilk iki kategorideki devletlerden daha büyük olan Üçüncü Dünya'daki küçük devletler. ${ }^{45}$ Fakat görüldügü üzere küçük devlet kavramının henüz kesin ve nihai bir tanımı yapılabilmiş değildir. Bu durum, Uluslararası İlişkiler disiplininde küçük devletlerin sorunlu bir yeri olduğunu gösterse de farklı tanımlama modellerini benimseyen yazarlar bu kavramı daha uzun bir süre kullanmaya devam edecek gibi görünmektedir.

Yukarıda ele alınan literatür niceliksel, niteliksel ve algısal yaklaşımlardan herhangi birini esas alarak yapılan tanımların küçük devlet kavramını muğlaklaştırdığını ve kavramın analitik değerini tartışmaya açtığını açık bir biçimde göstermektedir. Bize göre, küçük devlet kategorisi tanımlanırken herhangi bir kesin kriter koymadan toprak, nüfus, ekonomik gelişmişlik, gücü oluşturan askeri kapasite ve algı faktörleri birlikte göz önünde bulundurulmak suretiyle niceliksel, niteliksel ve algısal

41 Annette Baker Fox, “The Small States in International System, 1919-1969”, International Journal, Cilt 24, No.4, 1969, s.751-752.

42 Açar, Small State Playing the Asymmetric Game, s.22.

43 Raimo Värynen, "On the Definition and Measurement of Small Power Status", Cooperation and Conflict, Cilt 6, No.2, 1971, s.92-97.

44 Ibid., s.99.

45 Hey, "Introducing Small State Foreign Policy", s.2. 
yaklaşımları kapsayan bütüncül bir perspektif benimsenmelidir. Kesin sınırlar çizmeyen bu bütüncül perspektif, dünyanın çeşitli bölgelerindeki küçük devletlerin tespit edilmesini kolaylaştıracaktır. Burada, küçük devletlerin ikili ilişkiler üzerinden tanımlanmasının kavramı daha muğlak hale getirdiğinin altı çizilmelidir. Örneğin, Vatikan'ın Portekiz’e, Portekiz'in ise Almanya'ya göre küçük devlet olduğu açıktır. Bu devletleri ikili ilişkiler perspektifinden küçük devlet olarak tanımlamak göreceliliğe ve muğlaklığa yol açmaktadır.

Küçük devletler kategorisinin ikili ilişkiler yerine sistemik ve sistem-altı düzeylerde ele alınması kavramın Uluslararası İlişkiler disiplini açısından analitik değerinin artmasına katkı sağlayabilir. Farklı kıtalarda sistem-altı düzeyde var olan bütün devletler niceliksel, niteliksel ve algısal perspektiflerden ele alınarak hangilerinin küçük devlet kategorisine girdiği tespit edilebilir. Örneğin Batı Avrupa, Latin Amerika, Ortadoğu ve Uzak Doğu Asya gibi sistem-altı bölgelerde bulunan Belçika, Uruguay, Katar ve Singapur gibi ülkeler yüzölçümü, nüfus, ekonomi ve askeri kapasite bakımından kendi sistem altı-bölgelerinin küçük devletleri olarak rahatlıkla sınıflandırılabilir. Kısıtlı kapasitelerinin yanı sıra, bu devletlerin küresel sistem içinde büyük devlet olmak gibi bir iddiaları da bulunmamaktadır. Bu çerçevede, küçük devletler kategorisinin dünyanın farklı bölgelerinde test edilmesi, hem literatürün gelişimine katkı sağlayacak hem de küçük devlet kavramının Avrupa dışındaki bölgelerde kullanımını artıracaktır.

Küçük devletleri tanımlama hususunda karşılaşılan sorunlar, bu devletlerin dış politika davranışlarını açıklamayı hedefleyen çalışmalarda da kendisini göstermektedir. Makalenin bundan sonraki kısmında küçük devletlerin dış politikalarını inceleme yöntemlerine ve çatışan yaklaşımlara değinilecektir.

\section{Uluslararası İlişkiler Teorileri Çerçevesinde Küçük Devletlerin Dış Politikaları}

Küçük devletlerin dış politika davranışları, literatürün gelişimi boyunca farklı yazarların çatışan yaklaşımları nedeniyle, küçük devletleri tanımlamak kadar tartışmalı bir alan olagelmiştir. Jeanne Hey, Maurice East ve Michael Handel küçük devletlerin dış politika davranış kalıplarına dair kapsamlı liste hazırlayan yazarlardır. Bu üç yazarın çalışmalarına bakarak, küçük devletlerin ortak dış politika davranışlarını şu şekilde sıralayabiliriz: 1. Dünya meselelerine düşük düzeyli/profilde katılım; 2 . Uluslararası ve çok-uluslu örgütlere katılıma önem verme; 3 . Kısıtlı dış politika hedefleri izleme; 4. Politikalarını yakın coğrafi bölge ile sınırlama; 5. Diplomatik ve ekonomik araçları askeri araçlara tercih etme; 6. Dünya meselelerinde tarafsızlık politikası izleme; 7. Güvenlikleri için tamamen büyük devletlere dayanma (ittifak); 8. Güçlü devletlerle çatışmaya girmekten kaçınma; 9. Uluslararası hukuk, normlar, prensipler ve değerleri destekleme; 10. Uluslararası meselelerde işbirliğini destekleme. ${ }^{46}$

$\mathrm{Bu}$ liste realist Uluslararası İlişkiler kuramına yakın bir çerçevede, küçük devletlerin anarşik uluslararası sistem içinde kısıtlı kapasitelerinden dolayı daha çok güvenliğe ihtiyaç duyduklarını vurgulamaktadır. Ancak küçük devletlerin dış politikalarına dair tespit edilen bu davranışların birçoğu birbiriyle çelişmektedir. Bazı küçük devletler güvenliklerini sağlamak için büyük devletlerle ittifak kurma yoluna giderken, bazıları tarafsızlık politikası izlemeyi tercih etmektedir. Bu tip çelişkiler bizi, küçük devletlerin hangi şartlar altında farklı dış politika seçeneklerini tercih ettiğini veya dış politika

46 Handel, Weak States in the International System, s.53; East, "Size and Foreign Policy Behaviour", s.557; Hey, "Introducing Small State Foreign Policy”, s.5. Küçük devletlerin genel olarak dış politika davranışlarının bir değerlendirmesi için ayrica bkz. Kotchikian, The Dialectics of Small States, s.33-42. 
kararlarının özünde hangi nedensellik ilişkilerinin bulunduğunu incelemeye zorlamaktadır. Şu ana kadar yazarlar, küçük devletlerin dış politika davranışlarını anlamlandırmaya çalışırken iç (domestic) ya da dış (external) faktörlere odaklanmışlardır. ${ }^{47}$

Küçük devletlerin dış politikalarına dair literatüre katkıda bulunan yazarların Uluslararası İlişkiler kuramlarının etkisiyle konuya farklı perspektiflerden yaklaştığı ifade edilebilir. Küçük devletlerin dış politikalarını inceleyen çalışmalar ilk dönemlerde, bu devletler uluslararası sistemin zayıf ve savunmasız aktörleri olarak kabul edildikleri için, genellikle güvenlik meselesi etrafında şekillenmiştir. ${ }^{48}$ Realist kuram bağlamında, küçük devletlerin dış politika davranışlarında güvenliğin ve zayıflığın merkezi rolünün altını çizen birçok çalışma görülebilir. Örneğin, küçük devlet literatürünün gelişimine önemli katkı sağlayan Rothstein, eserlerinde temel olarak uluslararası sistemin zayıf aktörleri olarak küçük devletlerin güç dengesi sisteminde tehditler karşısında güvenliklerini garanti altına alabilmek ve hayatta kalabilmek için diğer devletlerle ittifak kurma politikası izlediklerini vurgulamıştır. ${ }^{49}$

Neorealist Uluslararası İlişkiler kuramının temel varsayımlarını esas alarak dış faktörlerin küçük devletlerin dış politika davranışlarını etkilediğini öne süren yazarlar, küçük devletleri anarşik uluslararası sistem nedeniyle kendi hayatta kalma mücadelelerini veren güçsüz özneler olarak kabul etmektedirler. ${ }^{50}$ $\mathrm{Bu}$ yazarlar, iç faktörleri tamamen göz ardı ederek, küçük devletlerin dış politika davranışlarının doğrudan uluslararası güç dağılımı (distribution of power) ya da tehdit dengesi (balance of threat) tarafından şekillendirildiğini öne sürmektedirler. Bu bağlamda, küçük devletlerin dış politikalarının uluslararası sistemde meydana gelen değişikliklerle uyumlu bir biçimde değiştiği iddia edilmektedir. ${ }^{51}$ Neorealist kuramın kurucu ismi Kenneth Waltz, küçük devletlerin güvenlik ve dış politikalarının sistemik kısıtlamalara ve büyük güçlerin mücadelelerine bağlı olduğunu öne sürmekte ve küçük devletlerin büyük güçlere göre sistem içinde daha dar manevra alanı olduğunu ifade etmektedir. ${ }^{52}$

Michael Handel, Waltz’un "uluslararası kısıtlamalar aktörlerin dış politika davranışlarını doğrudan şekillendirir” yaklaşımını esas alarak, küçük devletlerin içerisinde hareket ettikleri uluslararası ortamın bu devletlerin dış politikalarını etkileyen en önemli analiz düzeyi olduğunu öne sürmektedir. Handel, küçük devletleri uluslararası sistemin etkisiz aktörleri kabul ederek, bu devletlerin dış politika davranışlarını iç değişkenlerden ziyade uluslararası faktörlerin etkilediğini vurgulamaktadır. ${ }^{53}$ Annette Baker Fox da benzer şekilde uluslararası analiz düzeyinin küçük devletler üzerindeki belirleyici etkisinden bahsetmektedir. Buna göre, İkinci Dünya Savaşı sırasında Türkiye, Finlandiya, Norveç, İsveç ve İspanya gibi küçük devletlerin dış politika davranışları dış faktörlere, büyük güçlerin mücadelelerine ve savaşan büyük güçlerin bu devletlerden taleplerine göre şekillenmiştir. ${ }^{54}$

47 Hey, "Introducing Small State Foreign Policy", s.5-6.

48 Knudsen, “Small States, Latent and Extant”, s.187-188.

49 Rothstein, Alliances and Small Powers, s.186-191. Ayrica bkz. Marshall R. Singer, Weak States in a World of Powers: The Dynamics of International Relationships, New York, The Free Press, 1972; David Vital, “The Inequality of States: A Study of the Small Power in International Relations”, Christine Ingebritsen et.al. (der.), Small States in International Relations, Seattle, University of Washington Press, 2006, s.77-88.

50 Küçük devletlerin dış politika davranışlarını yapısal/sistemik açıdan açıklayan yazarların bir değerlendirmesi için bkz. Elman, "The Foreign Policies of Small States”, s.175-179.

51 Elman, "The Foreign Policies of Small States", s.171-172.

52 Kenneth Waltz, Theory of International Politics, Reading, Massachusetts, Addison-Wesley Publishing Company, 1979, s.184-185, 195.

53 Michael Handel, "Weak States in the International System”, Christine Ingebritsen et.al. (der.), Small States in International Relations, Seattle, University of Washington Press, 2006, s.149-150.

54 Fox, The Power of Small States: Diplomacy in World War II. 
Erling Bjøl, küçük devletlerin davranışlarının içinde bulundukları ve hareket ettikleri güvenlik coğrafyası ya da uluslararası sistem tipine (hegemonik sistemler, çatışmalı sistemler, entegrasyon sistemleri veya güvenlik toplulukları) uyumlu bir biçimde çeşitlilik gösterdiğini vurgulamaktadır. ${ }^{55}$ Hans Mouritzen de küçük devletlerin yer aldıkları farklı jeopolitik kümelerin onların dış politika davranışlarını doğrudan etkilediğini ifade etmektedir. ${ }^{56}$ Sonuç olarak, küçük devletlerin dış politikalarını neorealist kuram çerçevesinde inceleyen araştırmacıların ortak tarafı bu devletlere uluslararası sistemin öznesi değil nesnesi olarak yaklaşmalarıdır. Buna göre, küçük devletlerin dış politikaları güç dengesindeki dalgalanmalardan etkilenmekte ve bu devletler olaylara sadece cevap vermekte, bu olayları etkileyememektedirler. Bu bağlamda, neorealist kuramı esas alan çalışmalar dış politika yapıcılara herhangi bir önem atfetmemektedir. ${ }^{57}$

Küçük devletleri tamamen uluslararası sisteme bağlı ve etkisiz aktörler olarak ele alanlara karşı bazı yazarlar, bu devletlerin dış politika davranışlarını neoklasik realizm çerçevesinde iç faktörler üzerinden açılkamaya çalışmışlardır. Örneğin, Miriam Fendius Elman küçük devletlerin dış politika davranışlarının uluslararası sistemin kısıtlamalarından ya da birey/grup tercihlerinden ziyade iç kurumların etkisine bakılarak çalışılması gerektiğini savunmaktadır. Elman’a göre, kurumlar birbiriyle mücadele eden yerel dış politika gruplarından bağımsız olarak, farklı aktörlerin mümkün olan davranışlarının sınırlarını belirlemektedir. Elman, 1900 öncesi ABD örneğinden yola çıkarak kurumların hayati öneme sahip olduğunu çünkü kurumların tarihsel gelişim sürecinin daha sonradan meydana gelen siyasal süreçlerde aktörlerin tercih imkânlarını doğrudan etkilediğini ifade etmektedir. ${ }^{58}$

David McCraw da küçük devletlerin dış politikalarını etkileyen iç faktörlere dikkat çekmekte ve Yeni Zelanda örneğinden yola çıkarak bir ülkenin dış politikasının iktidara gelen farklı siyasal partilerin ideolojik yönelimlerinden doğrudan etkilendiğini öne sürmektedir. McCraw’a göre, Yeni Zelanda dış politikasında meydana gelen bazı değişikliklerin temelinde iktidara gelen İşçi Partisi'nin veya Ulusal Parti’nin dış politika anlayışları yatmaktadır. ${ }^{59}$ Benzer bir yaklaşımla Danimarka örneği üzerinde duran Fredrik Doeser, bu ülkenin dış politikasındaki değişiklikleri, siyasal parti muhalefetinin ve halk muhalefetinin etkileri gibi iç faktörler üzerinden ele almaktadır. Doeser'e göre, Danimarka'nın 1988 yılının ortalarında NATO'ya yönelik "dipnot politikası" olarak adlandırılan dış politikasını değiştirmesinde muhalefetteki değişimler etkili olmuştur. Doeser her ne kadar Danimarka'nın dış politika değişiminde iç ve dış faktörlerin eşit düzeyde önemli olduğunu belirtse de, farklı iç faktörlerin dış politikaya etkisini göstermesi bakımından önemli bir açılım sağlamıştır. ${ }^{60}$

Realist kuramın güvenlik merkezli yaklaşımına karşı liberal Uluslararası İlişkiler kuramı devletler arası iş birliğini mümkün görmekte, uluslararası kurumların büyük güçlerin hareket alanlarını kısıtladığını ve sorunlara barışçıl çözümler bulma yönünde katkı sağladığını vurgulamaktadır. Bu bağlamda Anders Wivel, Avrupa Birliği $(\mathrm{AB})$ örneğinden yola çıkarak, AB'nin kurumsal yapısının

55 Bjøl, “The Small State in International Politics”, s.29-34.

56 Hans Mouritzen, “Tension between the Strong, and the Strategies of the Weak”, Journal of Peace Research, Cilt 28, No.4, 1991, s.217-230.

57 Browning, "Small, Smart and Salient? Rethinking Identity in the Small States Literature", s.671-672.

58 Elman, "The Foreign Policies of Small States”, s.180-190.

59 David J. McCraw, "New Zealand's Foreign Policy under National and Labour Governments: Variations on the "Small State” Theme?”, Pacific Affairs, Cilt 64, No.1, 1994, s.7-8.

60 Fredrik Doeser, "Domestic Politics and Foreign Policy Change in Small States: The Fall of Danish Footnote Policy", Cooperation and Conflict, Cilt 46, No.2, 2011, s.223-224. Küçük devletlerin dış politika davranışlarını anlamak için yönetici elitlerin kimlikleri, tercihleri ve düşünceleri üzerinde duran yakın zamanlı bir çalışma için ayrıca bkz. Giorgi Gvalia et.al., "Thinking Outside the Bloc: Explaining the Foreign Policies of Small States", Security Studies, Cilt 22, No.1, 2013, s.98-131. 
küçük devletlere bölgesel büyük güçlerin güvenlik politikalarını etkileme ya da en azından Avrupa bölgesindeki güvenlik sorunlarının çözümü için endişelerini dile getirme imkânı verdiğini ifade etmektedir. Bu yaklaşıma göre, uluslararası kurumlar küçük devletlerin manevra ve etki alanlarını genişletmelerine olanak sağlamaktadır. ${ }^{61}$

Liberal kuramın önemle üzerinde durduğu bir diğer husus, küçük devletler nezdinde normların uluslararası arenadaki önemidir. Bu çerçevede Goetschel, küçük devletlerin uluslararası sistem içinde büyük devletlere karşı güç açığı bulunduğu için yok olma tehlikesiyle karşı karşıya kaldıklarını ve bu nedenle uluslararası normlar, prensipler ve kurallar konusunda değer-destekleyici (value-promotive) bir rol oynadıklarını öne sürmektedir. ${ }^{62}$ Christine Ingebritsen de kısıtlı ekonomik ve askeri kapasitesi olan küçük İskandinav devletlerini (İsveç, Norveç, Danimarka, Finlandiya ve İzlanda) uluslararası sistemin norm-girişimcileri (norm-entrepreneurs) olarak tanımlamakta ve bu devletlerin küresel işbirliği normları kurmak ve güçlendirmek suretiyle büyük devletleri aktif bir biçimde etkilemeye çalıştıklarını belirtmektedir. İskandinav ülkeleri sürdürülebilir kalkınma, çevre sorunları, ihtilafların barışçıl çözümü ve küresel gelir adaletsizliğinin geriletilmesi gibi hususlarda, uluslararası kurumsal katılım yoluyla, uluslararası politikaya norm-girişimcileri olarak katkıda bulunmaktadırlar. ${ }^{63}$

Realist ve liberal Uluslararası İlişkiler kuramlarının yanı sıra küçük devletlerin dış politikalarının anlaşılması için kullanılan bir diğer önemli kuram inşacılıktır (constructivism). Küçük devlet kavramına pozitif ya da negatif anlamlar yükleyen pozitivist yaklaşımların tersine inşacılık, yorumsamacı metodolojiyi benimsemekte ve aktörlerin kendilerini algılama biçimlerine ve söylemlerine odaklanmaktadır. İnşacı kurama göre, küçük devlet kimliği her zaman güçsüzlük ve kısıtlı hareket kapasitesi ile eşitlenmemelidir. Devlet kimliğinin inşasında küçüklügüü olumlu bir biçimde yorumlanması küçük devletlere dış politikada geniş imkânlar sağlayabilmektedir. Bu bağlamda, bazı devletler kendilerini küçük olarak tanımlamayı tercih ederek çevrelerinde daha fazla etki kazanma stratejisi izleyebilir. ${ }^{64}$ Christopher Browning, Finlandiya’nın küçük devlet kimliğinin Finli devlet adamlarının söylemleriyle farklı dönemlerde farklı biçimlerde inşa edildiğini, bunun bazen bir kısıtllılık bazen de fırsat ve kolaylaştırıcı olarak Finlandiya dış politikasını doğrudan etkilediğini vurgulamaktadir. ${ }^{65}$

\section{Küçük Devletlerin İttifak Davranışları}

Bir dış politika davranış biçimi olarak ittifak ${ }^{66}$ politikalarının, küçük devlet çalışmalarının gelişiminde önemli bir yeri bulunmaktadır. Küçük devletlerin ittifak politikalarını inceleyen çalışmalar, tıpkı küçük devletlerin dış politika davranışlarını inceleyen çalışmalar gibi, iç ve dış faktörlere odaklanmaktadır. Küçük devletlerin ittifak oluşumlarını inceleyen bazı yazarlar dış faktörlerin nedensel üstünlügüne atıfta bulunurken, diğer bir grup yazar iç faktörlerin belirleyiciliğine vurgu yapmaktadır.

\footnotetext{
61 Anders Wivel, “The Security Challenge of Small EU Member States: Interests, Identity and the Development of the EU as a Security Actor", Journal of Common Market Studies, Cilt 43, No.2, 2005, s.395.

62 Goetschel, "The Foreign and Security Policy Interests of Small States in Today's Europe”, s.23-26.

63 Christine Ingebritsen, "Norm Entrepreneurs: Scandinavia's Role in World Politics", Cooperation and Conflict, Cilt 37, No.1, 2002, s.11-23.

64 Browning, "Small, Smart and Salient? Rethinking Identity in the Small States Literature," s.673-674.

65 Ibid., s.674-681.

66 Bu çalışmada ittifak kavramı, geniş anlamda iki veya daha fazla egemen devlet arasında resmi ya da gayr-i resmi güvenlik iş birliği anlamında kullanılmaktadır. Bkz. Stephen Walt, The Origins of Alliances, Ithaca ve Londra, Cornell University Press, 1987, s.1; Michael N. Barnett ve Jack S. Levy, "Domestic Sources of Alliances and Alignments: The Case of Egypt, 1962-73”, International Organization, Cilt 45, No.3, 1991, s.370.
} 
Neorealist uluslararası ilişkiler kuramından etkilenen birinci grup yazarlar için küçük devletlerin ittifak davranışlarında uluslararası sistem belirleyicidir ve güvenlik kaygıları ön plandadır. Örneğin Rothstein, küçük devletlerin güç dengesi sistemi içinde (balance of power) güçlü devletlerle kurduğu ittifakların bu devletlerin güvenliği ve hayatta kalması için son derece önemli olduğunu vurgulamaktadır. Alliances and Small Powers adlı eserinde Rothstein, küçük devletler için iki tane ittifak seçeneği bulunduğunu belirtmektedir. Bunlardan ilki sadece büyük bir devletle kurulan ikili ittifak, ikincisi ise hem küçük hem büyük devletlerle kurulan karma/çok taraflı ittifaktır. Rothstein'e göre, küçük devletlerin güvenliğini sağlayan en iyi seçenek karma ittifaktır. ${ }^{67}$

İttifak teorilerinin gelişiminde Stephen Walt'un The Origins of Alliances isimli kitabının önemli bir yeri bulunmaktadır. Walt, Kenneth Waltz'un güç dengesi teorisini (balance of power theory) tehdit dengesi teorisine (balance of threat theory) dönüştürerek uluslararası ilişkilerde ittifak oluşumunu açılamaktadır. Walt, Waltz'un aksine, devletlerin temel olarak anarşik uluslararası sistemdeki güç dengesizliklerine karşı değil, dış tehditlere karşı ittifak kurduklarını öne sürmektedir. Walt'un tehdit dengesi teorisinde, dengeleme (balancing) öncelikli tehditlere karşı diğer devletlerle ittifak kurma anlamına gelirken, takip etme (bandwagoning) tehdit kaynağıyla ittifak kurma anlamına gelmektedir. ${ }^{68}$ Walt, küçük devletlerin büyük bir devlet tarafindan tehdit edildiğinde anarşik uluslararası sistemdeki savunması konumları nedeniyle dengelemeden ziyade takip etme politikası izlemeyi daha çok tercih edeceğini belirtmektedir. Walt, eğer tehdit eden büyük güç coğrafi olarak yakınsa ve ittifak yapacak alternatif bir büyük devlet yoksa küçük devletlerin takip etme stratejisi izlemelerinin daha büyük bir ihtimal olduğunu iddia etmektedir. ${ }^{69}$

Walt gibi, Eric Labs da dış faktörlerin küçük devletlerin ittifak oluşumundaki rolünü vurgulamaktadır. Labs’a göre, büyük bir devletin tehdidine karşı küçük devletlerin ittifak davranışı, ister dengeleme ister takip etme olsun, coğrafi yakınlık ya da diğer devletlerle uygun olan ittifak seçeneği gibi uluslararası sistemden kaynaklanmaktadır. ${ }^{70}$ Labs ayrıca, neorealist kuramın zayıf/küçük devletlerin dış politikasını güçlü bir biçimde açıkladığını ifade etmektedir. ${ }^{71}$

Küçük devletlerin ittifaklarını inceleyen ikinci grup yazarlar, neorealist kuramın ittifak davranışlarını açıklamada yetersiz olduğunu öne sürerek iç faktörlerin de göz önünde bulundurulması gerektiğini belirtmişlerdir. Örneğin Dan Reiter, küçük devletlerin ittifak davranışlarını dış faktörler yerine öğrenme teorisi (learning theory) üzerinden açıllamaktadır. Buna göre Reiter, Walt'un aksine, küçük devletlerin ittifak davranışlarının ve tercihlerinin uluslararası sistemden ve dış tehditlerden ziyade bu devletlerin tarihsel tecrübelerden edindikleri deneyimler tarafindan etkilendiğini öne sürmektedir. $^{72}$

Neoklasik realizmin en önemli temsilcilerinden biri olan Randall L. Schweller da devletleri sistem karşısında etkisiz gören anlayışı eleştirmektedir. Sistem-aktör geriliminde uluslararası sisteme karşı devletin öznesel gücünü vurgulayan Schweller, "devletlerin siyasi amaçlarını merkezine alan

67 Rothstein, Alliances and Small Powers, s.116-127. Küçük devletler ve ittifakları üzerine daha güncel bir çalışma için bkz. Erich Reiter ve Heinz Gärtner (der.), Small States and Alliances, Heidelberg, New York, Physica-Verlag, 2001.

68 Walt, The Origins of Alliances, s.17.

69 Ibid., s.25-31.

70 Eric J. Labs, “Do Weak States Bandwagon?”, Security Studies, Cilt 1, No.3, 1992, s.385-386.

71 Ibid., s.406.

72 Dan Reiter, "Learning, Realism, and Alliances: The Weight of the Shadow of the Past", World Politics, Cilt 46, No.4, 1994, s.519-520. 
bir alternatif ittifak teorisi” önermektedir. ${ }^{73}$ Schweller'a göre, devletlerin ittifak davranışları sadece tehdit veya tehlike yüzünden değil, ödül ve menfaat amacıyla da meydana gelmektedir. Bu bağlamda Schweller, ittifakları güvenlik ya da tehdit yerine menfaat ve kâr amacıyla analiz ettiği çıkar dengesi (balance of interest) teorisini ortaya koymaktadır. Schweller, Waltz ve Walt'un düşündügünün aksine uluslararası politikada takip etme politikasının daha yaygın olduğunu öne sürmektedir, çünkü "takip etme, cezalandırma tehdidi yerine ödüllendirme sözüyle hız kazanmaktadır.”74

Schweller'ın çıkar dengesi kavramsallaştırması sistem ve birim düzeylerini birlikte içermektedir. Dolayısıyla Schweller, devletler üzerinde var olan sistemik etkiyi reddetmemektedir. Schweller'n yaklaşımının ittifak teorilerine en önemli ve yeni katkısı, Waltz'un neorealist kuramının statüko önyargısı sebebiyle göz ardı ettiği revizyonist devletleri geri getirmek olmuştur. ${ }^{75}$ Çıkarları ittifak davranışının merkezine oturtan Schweller, devletleri birim düzeyinde dört kategoriye ayırmaktadır: aslanlar (güçlü statükocu devletler), kuzular (zayıf statükocu devletler), kurtlar (güçlü revizyonist devletler) ve çakallar (zayıf revizyonist devletler). ${ }^{76}$ Schweller, zayıf devletlerin uluslararası sistemin pasif aktörleri olmadıklarını ve uluslararası sistemin kısıtlayıcı etkilerine rağmen kendi ajandaları bulunduğunu belirtmektedir. $\mathrm{Bu}$ bağlamda Schweller, çakal takip etme (jackal bandwagoning) kavramsallaştırması ile revizyonist küçük devletlerin kendi çıkarları için ittifak arayışına girdiklerini öne sürmektedir. ${ }^{77}$

Üçüncü Dünya ülkelerinin ittifak oluşum sürecine odaklanan Steven David, Waltz'un güç dengesi teorisinin ittifak oluşumunda dış faktörlerin rolü, yani anarşik uluslararası sistemle meşgul olduğu için bu ülkelerin ittifak davranışlarını açıklamakta yetersiz kaldığını iddia etmektedir. David, temel olarak güç dengesi teorisinin ittifakların dış boyutuyla ilgilenmekte haklı olduğunu fakat Üçüncü Dünya ülkelerinin ittifak davranışları analiz edilirken iç tehditlerin de hesaba katılması gerektiğini ifade etmektedir. ${ }^{78}$ David, Üçüncü Dünya liderlerinin çalkantılı iç siyasi ortamda ayakta kalabilmek için, birincil tehditlere karşı ikincil tehditlerle iş birliği yapmak ve iç ve diş tehditleri birlikte dengelemek anlamina gelen her yerde dengeleme (omnibalancing) stratejisine başvurduklarını belirtmektedir. Fakat David'in her yerde dengeleme kavramsallaştırmasının güç dengesi teorisinin uluslararası anarşi, çıkarlar ve rasyonellik gibi temel çıkarımlarını göz ardı etmediği, Üçüncü Dünya'da ittifak oluşumunu anlamak için bunları iç faktörlerle desteklediği belirtilmelidir. ${ }^{79}$ David ittifak oluşumu teorisini geliştirirken küçük devletlerden ya da zayıf devletlerden bahsetmemiş olsa da, Üçüncü Dünya ülkelerinin birçoğu uluslararası sistemin küçük devletleri konumunda bulunduğundan her yerde dengeleme teorisi bu ülkelerin ittifak davranışını anlama açısından büyük önem arz etmektedir.

Küçük devletlerin dış politika ve ittifak davranışlarını iç ve dış faktörlere bakarak anlamlandırmaya çalışan yaklaşımlar arasında bulunan gerilimi çözmeye yönelik kapsamlı bir yaklaşım Jeanne Hey tarafından geliştirilmiştir. Hey, modelini geliştirirken temel olarak hem iç hem de sistemik faktörleri bir araya getirmeyi hedeflemiştir. James Rosenau'nun tümevarım (inductive) yönteminden

\footnotetext{
73 Randall L. Schweller, "Bandwagoning for Profit: Bringing the Revisionist State Back In”, International Security, Cilt 19, No.1, 1994, s.75.

74 Ibid., s.79.

75 Ibid., s.85-87.

76 Ibid., s.99-103.

77 Ibid., s.93.

78 Steven R. David, “Explaining Third World Alignment”, World Politics, Cilt 43, No.2, 1991, s.233-234.

79 Ibid., s.235-238.
} 
esinlenen Hey, küçük devletlerin dış politikalarının üç analiz düzeyine birlikte bakılarak incelenmesi gerektiğini ifade etmektedir. Bu analiz düzeylerinden ilki, küçük devletlerin bölgesel ve uluslararası dış faktörlerin etkilerine karşı savunmasızlığına odaklanan “sistemik analiz düzeyi”dir. Bu düzeyde küçük devletlerin güvenlikleri dikkate alınmaktadır. İkinci analiz düzeyi; bürokrasi, gelişmişlik düzeyi, devlet oluşumu, ulusal kültür ve nüfus baskısı gibi iç faktörlerin etkisini vurgulayan "devlet analiz düzeyi”dir. Üçüncü analiz düzeyi ise liderlerin ve dış politika danışmanlarının dış politika üzerindeki etkilerini inceleyen "bireysel analiz düzeyi” dir. ${ }^{80} \mathrm{Hey}$, küçük devletlerin dış politikaları incelenirken bu üç analiz düzeyinin birlikte göz önünde bulundurulması gerektiğini belirtmektedir. Hey ayrıca, daha önce ifade edilen sistemik yaklaşımların aksine, iç faktörlerin küçük devletlerin dış politikalarını güçlü bir biçimde etkilediği sonucuna ulaşmaktadır. ${ }^{81}$

Brenda Shaffer, Kafkasya’nın üç küçük devleti konumunda bulunan Azerbaycan, Gürcistan ve Ermenistan'ın Sovyet sonrası dönemde izledikleri dış politikanın dönüşümünü incelerken iç ve dış faktörleri birlikte ele almaktadır. Shaffer, Kafkasya'nın jeopolitik konumunun (Rusya’ya yakınlık) bu üç devletin dış politika stratejilerini ve ittifak davranışlarını farklı biçimlerde doğrudan etkilediğini vurgulamaktadır. Shaffer dış faktörlerin yanı sıra, iç faktörlerin (devlet gücü, rejim tipi ve liderlik) de bu devletlerin dış politikalarını etkilediğinin altını çizmektedir. Shaffer makalesinde, Sovyet sonrası dönemde Azerbaycan, Gürcistan ve Ermenistan dış politikalarının kimlik ve ideolojiden ziyade ulusal çıkar tarafından şekillendirildiği sonucuna ulaşmıştır. ${ }^{82}$

Görüldüğü gibi küçük devletlerin dış politika ve ittifak davranışları üzerine yapılan çalışmalar Uluslararası İlişkiler kuramlarından doğrudan etkilenmiştir. Küçük devletlerin dış politika ve ittifak davranışlarını inceleyen çalışmaların farklı kuramlardan etkilenmesi dünyanın çeşitli bölgelerinde bulunan küçük devletlerin çalışılması için önemli bir zemin oluşturmaktadır. Her ne kadar küçük devletlerin dış politika davranışlarını ve ittifak arayışlarını açıklamak için herhangi bir standart belirlemek mümkün olmasa da, iç ve dış etkenleri birlikte ele alarak bütüncül bir perspektiften yapılacak olan vaka çalışmaları disipline önemli kuramsal katkılarda bulunacaktır.

\section{Sonuç}

Yukarıdaki tartışmalarda görüldüğü üzere küçük devletler ve dış politikaları üzerine zengin bir literatür mevcuttur. Tarihsel perspektifte değişik zamanlarda değişik ülke grupları için kullanılan küçük devlet/küçük güç kavramının öncelikle tanımı üzerine önemli tartışmalar dikkat çekicidir. Niceliksel, niteliksel ve algısal olarak üç başlık altında incelediğimiz konu üzerine oluşan literatür bize tüm bu tartışmalara rağmen genel geçer tek bir tanım üzerinde anlaşılamadığını göstermiştir. $\mathrm{Bu}$ açık uçlu ve nereden bakıldığına göre değişen tanım, bir taraftan küçük devlet kategorisinin ne derece kabul gören ve üzerinde anlaşılan bir kavram olduğunun sorgulanmasına neden olurken, diğer taraftan araştırmacıların farklı kuramsal perspektiflerden konuyu ele almasına yol açmıştır. Makalede, bu üç yaklaşımın bütüncül bir perspektiften ele alınmasının küçük devlet kavramının analitik değerini artıracağı ifade edilmiştir.

80 Hey, "Introducing Small State Foreign Policy", s.10; Jeanne A. K. Hey, "Refining Our Understanding of Small State Foreign Policy”, Jeanne A. K. Hey (der.), Small States in World Politics: Explaining Foreign Policy Behavior, Boulder, Lynne Rienner Publishers, 2003, s.186.

81 Hey, "Refining Our Understanding of Small State Foreign Policy”, s.194.

82 Brenda Shaffer, "Foreign Policies of the States of the Caucasus: Evolution in the Post-Soviet Period", Uluslararast İlişkiler, Cilt 7, No.26, 2010, s.51-65. 
Tanımlamadaki zorluğa rağmen, küçük devletlerin dış politikalarını ele alan literatür Uluslararası İlişkiler disiplinindeki kuramsal tartışmaların yansıması olarak son derece önemli bir yer tutmaktadır. Tanımlamadaki farklılıklara paralel olarak, küçük devletlerin dış politika davranışlarını inceleyen eserlerdeki çeşitlilik de dikkat çekicidir. Bu literatür, gerek sistem-aktör dinamiklerini gerekse iç-dış etkenleri en temel noktaya koyması bakımından son derece önemli kuramsal tartışmaları yansıtmaktadır. Küçük devletlerin gerek tanımı gerekse dış politika ve ittifak davranışları üzerine önümüzdeki yıllarda yapılacak çalışmalarda farklı yaklaşımların devam edeceğini söylemek mümkündür. Özellikle küçük devletlerin dış politika ve ittifak davranışları hakkında örnek ülkeler ve vaka tartışmaları üzerinden yapılacak çalışmaların bu konudaki literatüre değişik şekillerde katkıda bulunacağı ve bu kategoriyi çok daha fazla kullanılır hale getireceği öngörülebilir. Yakın coğrafyasında pek çok küçük devlet bulunan Türkiye'de bu alandaki çalışmaların fazlalaşması da bu bağlamda önemli bir katkı olacaktır. 


\section{Kaynakça}

Açar, Dilaver Arıkan. Small State Playing the Asymmetric Game: Continuity and Change in Albanian Foreign Policy, Basılmamış Doktora Tezi, Ankara, Orta Doğu Teknik Üniversitesi, Sosyal Bilimler Enstitüsü, 2008.

Amstrup, Niels. “The Perennial Problem of Small States: A Survey of Research Efforts”, Cooperation and Conflict, Cilt 11, No.4, 1976, s.163-182.

Barnett, Michael N. ve Jack S. Levy. "Domestic Sources of Alliances and Alignments: The Case of Egypt, 1962 73”, International Organization, Cilt 45, No.3, 1991, s.369-395.

Barston, Roland P. “The External Relations of Small States”, August Schou ve Arne Olav Brundtland (der.), Small States in International Relations, Stockholm, Almqvist\&Wiksell, 1971, s.39-56.

Bauwens, Werner et. al. (der.). Small States and the Security Challenge in the New Europe, Londra, Brassey's, 1996.

Bjøl, Erling. “The Small State in International Politics”, August Schou ve Arne Olav Brundtland (der.), Small States in International Relations, Stockholm, Almqvist\&Wiksell, 1971, s.29-37.

Browning, Christopher S. "Small, Smart and Salient? Rethinking Identity in the Small States Literature", Cambridge Review of International Affairs, Cilt 19, No.4, 2006, s.669-684.

Crowards, Tom. "Defining the Category of Small States”, Journal of International Development, Cilt 14, No.2, 2002, s.143-179.

David, Steven R. "Explaining Third World Alignment”, World Politics, Cilt 43, No.2, 1991, s.233-256.

Doeser, Fredrik. "Domestic Politics and Foreign Policy Change in Small States: The Fall of Danish Footnote Policy”, Cooperation and Conflict, Cilt 46, No.2, 2011, s.222-241.

East, Maurice A. "Size and Foreign Policy Behaviour: A Test of Two Models”, World Politics, Cilt 25, No.4, 1973, s.556-576.

Elman, Miriam Fendius. “The Foreign Policies of Small States: Challenging Neorealism in Its Own Backyard”, British Journal of Political Science, Cilt 25, No.2, 1995, s.171-217.

Fox, Annette Baker. The Power of Small States: Diplomacy in World War II, Chicago, The University of Chicago Press, 1959.

Fox, Annette Baker. “The Small States in International System, 1919-1969”, International Journal, Cilt 24, No.4, 1969, s.751-764.

Goetschel, Laurent (der.). Small States Inside and Outside the European Union: Interests and Policies, Dordrecht, Kluwer Academic Publishers, 1998.

Goetschel, Laurent. “The Foreign and Security Policy Interests of Small States in Today's Europe”, Laurent Goetschel (der.), Small States Inside and Outside the European Union: Interests and Policies, Dordrecht, Kluwer Academic Publishers, 1998, s.13-31.

Goetschel, Laurent. Small States and the Common Foreign and Security Policy (CFSP) of the EU: A Comparative Analysis, Bern, Institut für Politikwissenschaft, 2000, NFP 42 Working Papers, Paper 14, s.1-122.

Gvalia, Giorgi, et. al. “Thinking Outside the Bloc: Explaining the Foreign Policies of Small States”, Security Studies, Cilt 22, No.1, 2013, s.98-131.

Handel, Michael. Weak States in the International System, Londra, Frank Cass, 1990.

Handel, Michael. “Weak States in the International System”, Christine Ingebritsen et. al. (der.), Small States in International Relations, Seattle, University of Washington Press, 2006, s.149-192.

Hey, Jeanne A. K. “Introducing Small State Foreign Policy”, Jeanne A. K Hey (der.), Small States in World Politics: Explaining Foreign Policy Behavior, Boulder, Lynne Rienner Publishers, 2003, s.1-11.

Hey, Jeanne A. K. "Refining Our Understanding of Small State Foreign Policy”, Jeanne A. K Hey (der.), Small States in World Politics: Explaining Foreign Policy Behavior, Boulder, Lynne Rienner Publishers, 2003, s.185195.

Höll, Otmar (der.). Small States in Europe and Dependence, Viyana, Wilhelm Brumüller, 1983. 
Inbar, Efraim ve Gabriel Sheffer. The National Security of Small States in Changing World, Londra, Frank Cass, 1997.

Ingebritsen, Christine. "Norm Entrepreneurs: Scandinavia’s Role in World Politics", Cooperation and Conflict, Cilt 37, No.1, 2002, s.11-23.

Katzenstein, Peter J. Small States in World Markets: Industrial Policy in Europe, Ithaca, Cornell University Press, 1985.

Keohane, Robert O. “Lilliputians' Dilemmas: Small States in International Politics”, Christine Ingebritsen et.al. (der.), Small States in International Relations, Seattle, University of Washington Press, 2006, s.55-76.

Keohane, Robert O. “Lilliputians' Dilemmas: Small States in International Politics”, International Organization, Cilt 23, No.2, 1969, s.291-310.

Keohane, Robert O. “The Big Influence of Small Allies”, Foreign Policy, Cilt 1, No.2, 1971, s.161-182.

Knudsen, Olav F. "Small States, Latent and Extant: Towards a General Perspective”, Journal of International Relations and Development, Cilt 5, No.2, 2002, s.182-198.

Kotchikian, Asbed. The Dialectics of Small States, Foreign Policy Making in Armenia and Georgia, Saarbrücken, VDM Verlag Dr. Müller, 2008.

Krasner, Stephen D. “Transforming International Regimes: What the Third World Wants and Why", International Studies Quarterly, Cilt 25, No.1, 1981, s.119-148.

Labs, Eric J. “Do Weak States Bandwagon?”, Security Studies, Cilt 1, No.3, 1992, s.383-416.

Liska, George. Alliances and the Third World, Baltimore, Johns Hopkins University Press, 1968.

Mathisen, Trygve. The Functions of Small States in the Strategies of the Great Powers, Oslo, Universitetsforlaget, 1971.

McCraw, David J. "New Zealand's Foreign Policy under National and Labour Governments: Variations on the "Small State” Theme?", Pacific Affairs, Cilt 64, No.1, 1994, s.7-25.

Mouritzen, Hans. "Tension between the Strong, and the Strategies of the Weak", Journal of Peace Research, Cilt 28, No.4, 1991, s.217-230.

Neumann, Iver B. ve Sieglinde Gstöhl. "Introduction: Lilliputians in Gulliver's World”, Christine Ingebritsen et.al. (der.), Small States in International Relations, Seattle, University of Washington Press, 2006, s.3-36.

Ólaffson, Björn G. Small States in the Global System: Analysis and Illustrations from the Case of Iceland, Aldershot, Ashgate, 1998.

Ott, Dana. Small is Democratic: An Examination of State Size and Democratic Development, New York, Garland Publishing, 2000.

Payne, Anthony. "Small States in the Global Politics of Development", The Round Table: The Commonwealth Journal of International Affairs, Cilt 93, No.3, 2004, s.623-635.

Reiter, Dan. "Learning, Realism, and Alliances: The Weight of the Shadow of the Past", World Politics, Cilt 46, No.4, 1994, s.490-526.

Reiter, Erich ve Heinz Gärtner (der.). Small States and Alliances, Heidelberg, New York, Physica-Verlag, 2001.

Rothstein, Robert L. Alliances and Small Powers, New York, Columbia University Press, 1968.

Rothstein, Robert L. "Alignment, Nonalignment, and Small Powers: 1945-1965", International Organization, Cilt 20, No.3, 1966, s.397-418.

Schweller, Randall L. "Bandwagoning for Profit: Bringing the Revisionist State Back In", International Security, Cilt 19, No.1, 1994, s.72-107.

Shaffer, Brenda. "Foreign Policies of the States of the Caucasus: Evolution in the Post-Soviet Period", Uluslararast İlişkiler, Cilt 7, No.26, 2010, s.51-65.

Singer, Marshall R. Weak States in a World of Powers: The Dynamics of International Relationships, New York, The Free Press, 1972. 
Small States. http://secretariat.thecommonwealth.org/Internal/180407/ (Erişim Tarihi: 10 Ağustos 2015).

Steinmetz, Robert ve Anders Wivel. “Introduction", Robert Steinmetz ve Anders Wivel (der.), Small States in Europe: Challenges and Opportunities, Aldershot, Ashgate, 2010, s.3-14.

Värynen, Raimo. "On the Definition and Measurement of Small Power Status", Cooperation and Conflict, Cilt 6, No.2, 1971, s.91-102.

Vellut, Jean-Luc. "Smaller States and the Problem of War and Peace: Some Consequences of the Emergence of Smaller States in Africa", Journal of Peace Research, Cilt 4, No.3, 1967, s.252-269.

Vital, David. The Inequality of States: A Study of Small Power in International Relations, Oxford, Clarendon Press, 1967.

Vital, David. "The Inequality of States: A Study of the Small Power in International Relations", Christine Ingebritsen et.al. (der.), Small States in International Relations, Seattle, University of Washington Press, 2006, s.77-88.

Vital, David. The Survival of Small States: Studies in Small Power/Great Power Conflict, Oxford, Oxford University Press, 1971.

Walt, Stephen. The Origins of Alliances, Ithaca ve Londra, Cornell University Press, 1987.

Waltz, Kenneth. Theory of International Politics, Reading, Massachusetts, Addison-Wesley Publishing Company, 1979.

Wivel, Anders. "The Security Challenge of Small EU Member States: Interests, Identity and the Development of the EU as a Security Actor", Journal of Common Market Studies, Cilt 43, No.2, 2005, s.393-412. 